\title{
New career models in UK professional service firms: From up-or-out to up-and-going-nowhere?
}

\author{
Namrata Malhotra \\ Imperial College Business School \\ Imperial College London \\ South Kensington Campus, \\ London SW7 2AZ \\ n.malhotra@imperial.ac.uk \\ Timothy Morris \\ Saïd Business School \\ University of Oxford \\ Park End Street \\ Oxford OX1 1HP \\ tim.morris@sbs.ox.ac.uk \\ Michael Smets \\ Saïd Business School \\ University of Oxford \\ Park End Street \\ Oxford OX1 1HP \\ michael.smets@sbs.ox.ac.uk
}




\title{
New career models in UK professional service firms: From up-or-out to up-and-going-nowhere?
}

\begin{abstract}
In this paper, we empirically examine how professional service firms are adapting their promotion and career models to new market and institutional pressures, without losing the benefits of the traditional up-or-out tournament. Based on an indepth qualitative study of ten large UK based law firms we find that most of these firms do not have a formal up-or-out policy but that the up-or-out rule operates in practice. We also find that most firms have introduced alternative roles and a novel career policy that offers a holistic learning and development deal to associates without any expectation that unsuccessful candidates for promotion to partner should quit the firm. While this policy and the new roles formally contradict the principle of up-or out by creating permanent non-partner positions, in practice they coexist. We conclude that the motivational power of the up-or-out tournament remains intact, notwithstanding the changes to the internal labour market structure of these professional service firms.
\end{abstract}

Keywords: careers, tournament promotions, professional service firms

Contact address for correspondence:n.malhotra@ic.ac.uk 


\section{Introduction}

Knowledge intensive firms (KIFs) are said to be the exemplars of many of the trends that affect other sorts of organisation, including the growing reliance upon expert labour to deliver services and develop innovations (Starbuck, 1992; Greenwood, Li, Prakash and Deephouse, 2005). They play an increasingly important role in economic activity as facilitators of transactions and providers of expertise for public as well as private sector organisations (Sharma 1997). Professional service firms including law, accounting, architecture and engineering consulting firms constitute one part of the wider set of KIFs (Greenwood, Suddaby and McDougald, 2006). Professional service firms have been under pressure for over a decade to become more corporate or business-like in their structures and systems. Changes in the labour market situation and the war for talent have especially challenged the promotion to partner tournament model, or up-or-out, that has long been the norm in elite professional service firms. It has been argued that in recent years this model has been substantially reformed or even abandoned under pressure from market and institutional changes. This paper examines this argument in the context of a set of major corporate law firms, looking in depth at the innovations they have introduced, how these affect the working of an up-or-out promotion system and the response of their professional staff to these innovations. We ask how firms seek to adapt their internal labour markets while maintaining the underlying benefits of the up-our-out model for selecting partners.

\section{The Up-or-Out Promotion Model}

The up-or-out model is a form of tournament promotion (Galanter and Palay 1991; Gilson and Mnookin 1985; Kordana 1997; Lazear and Rosen 1981; Landers, 
Rebitzer and Taylor 1996; Wilkins and Gulati 1998). In economic theory, tournament candidates compete against each other for promotion to a limited number of positions at the next grade within a certain time period and promotion is based on relative ranking within the cohort rather than any individual's absolute merits. Those that fail to make the grade are barred from subsequent promotion rounds (or tournaments) and, in the up-or-out version of the tournament, expected to leave the firm. In professional service firm settings, the internal labour market structure essentially constitutes two grades of professional staff: associates and partners. The critical tournament occurs when associates seek promotion to partner. Partnership is desirable because partners typically have an ownership stake in the firm and therefore share profits. Partners play a critical role in winning and running client relationships as well as running professional teams in executing client assignments (Malos and Campion 1995). The decision to promote an associate therefore has important ramifications for the firm's reputation, ability to generate future profits and how many individuals will share the total profits of the firm (Hitt et al 2001).

Up-or-out is a strongly embedded institution in elite professional firms. It originated in the elite New York law firms in the early years of the twentieth century as part of a process in which these firms institutionalised their employment models, ownership form and governance (Galanter and Palay 1991). The 'Cravath’ system of hiring a relatively permanent group of non-partner lawyers and creating a competition for internal promotion to partner was the first instance of an up-or-out model, widely adopted by leading New York law firms (Sherer, 1995 ) and then by firms in the UK as well as in other professional services sectors such as management consulting and accounting (Morris and Pinnington 1998). The up-or out model developed into an 
industry norm in conditions of stable and growing supply and demand for legal work (Galanter and Palay 1991). Demand growth occurred as corporations, the clients of major professional service firms, diversified and internationalised their operations. Supply side growth was driven by the increasing number of graduates who sought to enter the professions.

Theoretically, internal labour markets based on up-or-out promotions present a number of puzzles. From the firm's point of view, it seems perverse to incur the costs of hiring and training valuable personnel over a period of years only to fire the majority of them as they reach their most productive levels and replace them with other cohorts that have to be trained. From the individual's point of view, the risks of joining a firm when only a small minority make partner raise questions about why the individual would want to enter such a contract as well: Starbuck (1992) indicated that only about $10 \%$ of hires into the elite law firms in New York were promoted to partner.

The preference for the up-or-out model in professional firms is explained by its incentive properties, supported by an informal contract between employees and firm to make a promotion decision within a defined period. For the firm, up-or-out resolves the problem of how to sustain performance among employees in a production process where the output is complex and intangible. This means not only that effort is difficult to measure but also that the relationship between employee input (work effort) and output is complex. In such situations, monitoring costs are potentially substantial and the job of monitoring is itself difficult because partners or senior professionals are themselves engaged in production rather than management. An up- 
or-out promotion model provides the alternative of a relatively cheap incentive: employees sustain high effort and seek to develop competence in order to win the tournament prize of promotion to partner and the share of profits, as well as status rewards, which go with it. Further, because the firm risks diluting profits per partner if it offers more new partnership positions than it can sustain, the model allows it to limit the number promoted at any one time and select only those it considers most appropriate. Because the criteria for promotion are complex and candidates are informally selected over a long period of working with partners, the system induces high effort levels, in terms of hours worked, which Landers et al (1996) found was the best proxy for quality.

By ensuring that candidates who fail to make partner leave rather than stay as non-partner associates, the firm resolves certain risks as well. First, it avoids the likely increased monitoring costs it would incur with passed-over candidates who therefore lack the incentive of promotion to partner at a future point. Second, it frees up a development path to senior positions for aspiring and competent associates that might otherwise be held by passed over candidates. Third, it allows the firm to align its employment profile (known as its leverage ratio) with its business model: a stock of career-plateaued associates are likely to be expensive to employ and unless the firm can generate enough work of an appropriate level of complexity, these associates will be engaged in routine tasks which could be passed to juniors or para-professionals.

But why should employees take the risk of entering the tournament for promotion with such low odds of success? Gilson and Mnookin (1989) suggest that the quid pro quo for taking this risk is that employees are tacitly assured the 
promotion decision will take place within a finite period, so that they are not left hanging on indefinitely. In the process of preparing for the tournament the associate gains valuable general human capital which can be used to gain another position in the event of failure to achieve partnership. In some elite professional firms the implicit contract between the firm and failed candidates is that the firm will actively help to place them with a client: McKinsey and Accenture are two firms that have such a reputation, both maintaining strong links with their 'alumni' not least because of the future business opportunities that can flow from them. The up-or-out model therefore has benefits for both parties: it generates high productivity with low monitoring costs for the firm and general (as well as firm-specific) human capital development for the individual.

However, a number of scholars argue that the up-or-out model has been subject to modifications over time and in practice differs substantially from the ideal type. Indeed, in their original specification of the 'tournament of lawyers' Galanter and Palay (1991) propose that the era of the classic tournament was in the late 1950s and early 1960s and that changes in the market environment had induced changes by the 1980s. Wilkins and Gulati (1998) go further by questioning the underlying model of a tournament in relation to law firm practices in the context of large law firms in the US. They argue that 'the standard economic model of tournament is not an appropriate model for analyzing the internal labor markets of large law firms.' (p1587).

Wilkins and Gulati (1998) do not present systematic data to support their claims but draw on a mix of secondary data and close familiarity with the American 
legal profession. Drawing on sporting tournament models they identify a number of practices to support their argument, including seeding and tracking employees, which weed out certain candidates or advantage others before the actual promotion decision has been made, reliance on several forms of incentive in addition to the promotion promise, selection on the assumption that not all associates seek the prize of promotion to partner and multiple decision making rounds before the final round. They suggest associates work hard not so much because of the incentive of promotion but because of socialisation to professional norms while undergoing formal training at university or law school. However, they conclude that the tournament is a useful metaphor for describing the internal labour market policies of law firms and that this persists as an institutionalised norm among elite firms as a result of the twin needs of firms to monitor performance cheaply and provide development in order to create sufficiently competent associates at different grades.

Galanter and Henderson (2008) also revisit Galanter and Palay’s original model of a promotion to partner tournament some twenty years after the fieldwork was completed. They propose 'a more complex and elongated tournament structure that applies to both partners and associates' which they call the 'elastic tournament'. This form of tournament has permanent 'off-track' attorneys, that is lawyers who have been passed over for promotion to partner but nonetheless remain in permanent positions, as well as partners without access to equity working. These groups sit outside the core of the firm in which the promotion to partner model persists; inside the core are associates on track for partnership and those partners who control access to key clients. In other words, the internal labour market of these firms has become more differentiated although the tournament model still sits at the heart of the firm. 
The general proposition is therefore that the tournament promotion model persists in a modified form but several factors challenge its viability. On the supply side, there is evidence that larger proportions of associates join firms not to pursue lifelong careers and therefore participate in the tournament but as a relatively short term job wherein they will receive some on-the-job training and experience. The long hours of the typical professional career is said to be incompatible with the aspirations of many employees and with those who seek to balance work and family demands. Of relevance here is the increased number of women who have entered the professions over $50 \%$ of all entrants to the legal profession in the last five years are female - who are said to find it difficult to reconcile taking primary responsibility for raising a family and the hours required to fulfil client duties which are an important factor in selection for partner. As a result, many professional firms find it difficult to retain sufficient numbers of talented associates long enough to sustain a meaningful tournament to partner.

Greater diversity in the portfolio of practices and internationalization have made it more difficult to have a single firm-wide tournament model. Different practices and geographic offices operate with different business models and leverage requirements (the associate to partner ratio). Novel human resource strategies such as hiring partners and associates laterally from the external market also challenge the internal labour market structure (Sherer 1995; Sherer and Lee 2002). Yet to the extent that the tournament promotion model offers substantial motivational benefits and is strongly institutionalised as a signal of professional meritocracy and excellence (Wilkins and Gulati 1998) its abandonment can be predicted to be costly and difficult. The research question following from that is: How are firms responding to the market 
and institutional pressures on the tournament promotion model? In this study, we empirically examine how elite law firms are adapting their promotion and career models to changed circumstances without losing the benefits of the tournament.

\section{Methods}

\section{Research Context and Sample}

Our research site for the study is elite corporate law firms, headquartered in the UK. In these firms the promotion to partner decision typically takes place between six and ten years after professional qualification, depending on the area of legal practice and the nature of the labour and client markets. Our sample for the study includes ten large corporate law firms. The legal media outlets have been replete with examples of innovative changes to the promotion system being introduced in UK based corporate law firms. We examine the logic underlying changes in the promotion system,, in what ways and the extent to which change has occurred. In order to gain a comprehensive understanding of the changes and their implications we interviewed different actors including associates, HR directors, managing partners and other partners in each firm. Our study goes further than previous research which has either been based on secondary sources or relied principally on single respondent accounts of formal policy in firms.

The research design involved the following steps: i) assembling data on the labour market context in which law firms operate ii) documenting the formal promotion policies of firms in this context and the intent behind these policies as well as understanding how they were changing (if at all) and clarifying any differences between espoused policies and those actually in use; iii) examining attitudes among a 
range of actors within each firm to the promotion policies and how they reacted to actual or proposed changes. We focussed on managing partners and human resource directors, the architects of firm policies, in order to understand their intentions and perceptions of how these were enacted in our first set of interviews in firms and then we interviewed associates and those in new career roles as the key recipients of these promotion policies. We also interviewed junior and more senior partners as they have an interest in these policies and influence over policy decisions and how they are enacted.

\section{Data sources}

We thoroughly scanned reports appearing in the legal media over the past five years to capture the broad context of how career issues were perceived and the policy responses of firms. Over the period 2007-8, 33.8\% of news items (380 in total) in The Lawyer Daily online newsletter related to issues of promotion to partnership and alternatives to partnership while $27 \%$ of newsletter headlines were about these topics. We documented different themes appearing in the media related to the tournament system of promotion including the types of pressures on the practice and the alternatives being proposed and discussed. This enabled us to familiarise ourselves with the context in which the firms were operating and to check that the firms in our sample appeared representative of the wider population of large law firms.

We obtained data for this study from documentary analysis and in-depth interviews in ten elite UK law firms. We refer to these as L1-L10. These firms are all in the top 30 firms by size (fees and partners) and compete with each other for client business as well as in the labour market. Documentary sources included websites and intranets where policies are typically outlined in some depth and discussion pages 
allow feedback on policy proposals. We also reviewed formal policy documents where these were available. Having obtained information about each firm's promotion policy we conducted interviews with the HR Director, the Managing Partner and/or a Partner responsible for promotions and careers, associates and other partners in each firm. We used themes from the media reports as trigger questions but kept the interview as open ended as possible. Each interview lasted about one hour.

\section{Data Analysis}

We conducted a thorough content analysis of media reports, firm level documents and interviews. We tracked new practices and policies shaping careers in large law firms that were reported by the media and in the firms we studied. Interviewees were asked to elaborate on any new practices that had been introduced over the past few years. We analyzed the different interpretations given to those practices and different understandings of their consequences for the up-or-out model.

\section{Firm Level Changes}

Documentary evidence from firms and media accounts revealed important differences between firms in the patterns of their internal labour market, so we asked the managing partners and HR directors to clarify the formal policy position of their firms. They detailed different types of alternative roles to partnership that had been formally adopted in the firms. Table 1 in the appendix summarizes the types of roles that had been formally introduced in each firm. Evidence of new alternative roles raised the question for us about the status of the up-or-out tournament. Did the introduction of alternatives to partner mean that the up-or-out tournament was being replaced? We delved into this issue in the interviews with the HR Directors, associates, managing partners and other partners. We also asked these officers if, in 
their view, the firm in which they worked had an up-or-out promotion policy. In six of the ten firms, the managing partner who has formal authority for the management of the firm and is similar to a chief executive officer, answered in the affirmative. In three firms the answer was no. In one case, the managing partner said that there was no formal policy but a de facto arrangement existed. In the three firms in which there was no up-or-out the managing partners said that this sort of policy would be desirable for motivational reasons but they did not feel the firms were in a strong enough position to run such a competition for partnership and that they had difficulty holding onto enough high quality associates. In the firms where there was an up-orout, the managing partners stated that it was not highly formalized, that is written down and explicitly re-affirmed to associates, nor were unsuccessful candidates dismissed within a strict time-period. Rather it was taken for granted by all concerned that there were no long term permanent associate positions. In contrast, in only one firm did the HR director (in L4) indicate that up-or-out operated. We discuss in detail different actors' understanding of the promotion model after we have described the new roles that allowed associates to come off the career track to partner. These new roles include Of Counsel, Permanent Associates, Professional Support Lawyers, Salaried Partners and Legal Director.

Alternatives to Partnership Overall, we observed that the majority of firms in our sample had formally adopted alternative roles as part of firm policy. We also gathered data on the compensation and promotion policies with regard to these new roles as they were relevant to the question of how firms sought to motivate individuals not on the promotion to partner track. We also explored with all of our interviewees what 
they understood by the purpose of these roles and how they affected the existing promotion system.

Of Counsel: The title Of Counsel/Counsel is reserved for senior associates who either have not made partner or have not applied to do so, but are at least eight years qualified. Therefore they should be at or beyond the level of experience required for promotion to partnership, but usually lack a strong enough business case to be selected. This role has been introduced by seven firms, the exceptions being L4, L8 and L10. (L1 uses the term Counsel but this is simply a semantic difference). In L2, a formal proposal to introduce the role and title had been put forward by the HR function, but was rejected by the firm's executive committee. Nonetheless, it was acknowledged that some of L2's practices and non-UK offices used the term and had appointed associates to the role. In L9, L6, L5, L3 and L1, the role had been formally created in the last two years and entailed clear criteria for selection. L7 had just set the role up and was appointing its first Of Counsel when we began our interviews with that firm: we returned over a period of nine months to check progress and the role was successfully filled by twelve lawyers. In the case of L1, the Counsel title was described as a rationalization exercise to sweep up the various titles emerging to describe associates in permanent positions.

The remuneration Of Counsel differed from that of associates. In all but L6, their base remuneration was higher than that of senior associates. In addition, they had bonuses linked to firm performance while the associates' bonus was more closely linked to individual and practice performance. In L1 and L5 Of Counsel bonuses were linked to the profits of the partnership; in L3, L9 and L7 it was linked to individual as 
well as firm performance. In L2, where the Of Counsel role exists in specific offices or practice areas, informal bonus arrangements link remuneration to local practice or office performance. We asked the HR directors and the managing partners to explain the logic of the remuneration policies. The most important factor was to link the Of Counsel's pay to that of the firm or practice in which they worked partly as a motivating device and partly so that their pay was seen as based on a similar principle to the profit-based rewards of partners.

There were marked differences across firms in the future career prospects for Of Counsel lawyers. L1, L3 and L9 did not expect them to be future candidates for partnership. In L6 and L5, Of Counsel lawyers could subsequently be proposed for partnership selection provided a sufficiently strong business case could be made although it was assumed that without considerable control of clients this was impracticable. In L2 the situation was complicated because formal policy indicated there was no route but the practice of certain groups in the firm was to support individuals applying for partnership and in a small number of cases they had been successful. L7 was considering the implications when we first interviewed the HR director and subsequently decided to offer a route to partnership for Of Counsel. In general this was seen by HR directors and managing partners to be a highly contentious issue because of its implications for the existing promotion to partner models, which included selection criteria, competences and development tracks inside the firm.

Permanent Associates: Although it was accepted fact in all respondent firms that permanent associates existed and had done so for many years, the formalization of this role and the growth in the numbers now occupying this role differed. For example 
in L3 the number of permanent associations had increased from 16 to 90 since 1999. Even in L4, which had the most explicit up-or-out policy, the head of HR estimated that 25 out of a population of 350 associates were permanent, because they were “covering an important issue or they were being strung along by partners who feared tackling the problem.” Permanent associates are generally those associates who are eight or more years qualified and have failed to obtain partnership or will not be put up for promotion. Permanent associate positions tend to be concentrated in areas with a strong need for experienced lawyers but a weak business case for partnership. As a partner in L5 said:

They wouldn't work in my area, corporate law, because they block the way for younger lawyers and they are too expensive to justify. But in tax they would be useful.

Only in L7, L8 and L10 were permanent associates formally recognised. These firms operated with a different internal labour market model from the others in that they had no up-or-out in policy and practice terms, and therefore the permanent associate model did not present a contradiction for the firm or associates and partners. Intriguingly, these firms had also introduced Of Counsel and other new positions alongside the permanent associate role. These innovations had partly been driven by competitive concerns in the labour market but they were part of broader innovations by HR directors in the way they positioned the career proposition to actual and potential employees, which we discuss below.

Professional Support Lawyers: PSLs are qualified lawyers who provide supporting tasks for fee earning lawyers. Many are technical specialists with strong drafting skills which are used to resolve legal difficulties during transactions. PSLs hold permanent positions, but have not traditionally been on a partnership track and have therefore 
been seen as following an alternative path to that of the career lawyer. This role is not new, having existed for over twenty years in our sample of firms, but until recently it was very rare. The proportion of PSLs to associates remains relatively small: for instance, in L4 there are 25 PSLs and 350 associates; in L3 there are 30 PSLs to 450 associates and in L2 there are 30 PSLs to 1000 associates.

What is important about the development of this role, however, is that it has become a popular means of resolving 'work/life balance' issues because PSLs are not directly fee earning and can therefore manage working hours more flexibly. The expansion of numbers in this role represents a deliberate policy innovation to the core internal labour market structure based around associates working directly for partners. We asked why firms had expanded the number of PSLs. In L1, L2, L3, L5 and L9 the PSL role is acknowledged to be a means of retaining associates. In L4 the creation of PSLs was a practice group decision in particular practice groups either for retention purposes or to build expertise. Formal firm-wide policy on the specifications of the role was deliberately loose although it was clear that PSLs could not become partner. In L7, L8 and L10 PSLs were also being expanded for a mix of retention and expertise building purposes. In each firm the large majority of PSLs are females (for instance, in L2 98\% and in L3 95\% of PSLs are female) and interviewees explained that many have taken the role to fit with raising a family. In no firm was the PSL on a partner track although the medium term intent in four firms ( L2, L3 and L5, L9) was to permit PSLs to move back into fee earning and re-enter the partnership track as associates. In addition, in these firms policy developments are focussing on widening the role to connect it more closely to business development activities and therefore establish a stronger link to the factors that underlie partnership selection. In L1 and L7, policy initiatives were in place to create a career track to Managing PSL; in L7 
there was ongoing discussion whether to link that to access to possible partnership selection. PSLs were typically paid a salary linked to associate rates but with limited bonus opportunities. All were subject to appraisal systems linked to salary progression.

Salaried Partners: Apart from Firm L4, each of the elite firms has had a two tier partnership until recently. This has allowed them to promote to partner status without committing to a permanent equity partnership position before reviewing the performance of the individual in a partner role. The underlying assumption was that despite careful selection not all candidates fulfil expectations and acquire enough business to justify their profit share. It also allowed firms to regulate the size of the equity pool to maintain profits per equity partner, the crucial measure of financial performance of a partnership, at a competitive level. Salaried partners are normally reviewed for entry to equity partnership after performing the distinctive tasks of a partner for a period of two to four years. Hence, the salaried partner role represents an important means of moderating the up-or-out model by distinguishing between partners as owners and partners as employees and prolonging the process through two stages.

Over the last two years L9 has changed its partnership to an all-equity model. L1 has taken steps to reduce the status and reward differences between salaried and equity partners and has also removed the distinction between local and international partners across its foreign offices to enhance the idea of a single, homogenous partnership. L2 and L5 argued that salaried partnership was a means of managing different status expectations in its foreign offices and enhanced the chances of equity partnership by giving candidates status and the time to show they could develop a 
practice. L3 likewise saw the two stage partnership as a benefit for candidates rather than a further restriction. In each case, the assumption was that election to salaried partnership signalled the firm's belief that the candidate would subsequently make equity partner. In each of these firms, the policy was to reduce the size of the salaried partner pool and to emphasise that there could be no permanent salaried partner positions. When asked if salaried partnership was in practice an up-or-out process, HR directors and partners said that the likelihood of not making equity partner was small and that it only happened in exceptional circumstances, usually because the business case did not add up. Achieving salaried partnership was the most difficult step in the promotion process and there was a high probability of upwards promotion to equity partnership.

In L7, L8 and L10 salaried partnership was more permanent. We found evidence of longer term tenure of salaried partner positions and higher proportions of salaried to equity partners: in the other firms this was around 50:50 while in these three the ratio was 70:30. However, these firms said salaried partners were not formally appointed on a permanent basis. These firms indicated that this situation had developed as they sought to improve the profit per equity partner ratio in order to recruit laterally but acknowledged there were motivational risks for current and future incumbents in creating permanent salaried partners. The intention was to reduce the ratio to around 50:50 over the medium term.

L4 is also an outlier. It has an all-equity partnership and elects its partners relatively early. It holds the view that its homogenous internal structure and close collaboration between working teams enable it to elect straight to equity, but accepted 
that its partnership size has been relatively stable over the last ten years so that the probabilities of promotion to partner are relatively low.

Legal Director: Firm L6 has created a Legal Director role. Compared to a Senior Associate a Legal Director is given more management information and a special status and respect. A Legal Director does much the same as Partners but is not required to go out and get work and do the degree of business development that is expected of Partners. The creation of this role seemed to be an experiment to retain senior personnel running alongside the Of Counsel model, mainly driven by internal preferences and it was unclear whether the two roles would remain separate in the long run.

Accounts of the key actors in explaining the promotion model. We reviewed the accounts of each of the key actor groups in discussing how the promotion model inside the firm operated and how it was changing. This provided us with important insights into the working of the internal labour market and the interaction of formal policy intent with actual practice. We summarise each major group below.

HR Managers Across all the firms in the sample (except one) we found that HR Managers were actively working on the development of these new roles and changes to career paths. They engaged in policy innovation backed by suitable rhetoric, to justify alternative roles and career paths. The starting point was that innovation in career systems was necessary to accommodate the emerging needs of young lawyers. For example, the HR manager in Firm L2 said:

We don't have a shortage of associates wanting to be a partner but the career proposition here is based on the fact that for some, 
a large number, partnership is not the aim. (HR Manager, Firm L2)

The response was to focus on career development as a more encompassing proposition than the promotion to partner model. In seven of our sample firms, HR managers had devised a structured career development process that emphasized individual skill development and valuable experience which would enhance associates’ market value and take them up through the ranks of their current firm. For example in Firm L1, a framework called "the deal" laid out a set of commitments from the firm to provide interesting and stimulating work for associates on "leading edge” transactions, focussing on complex cases and avoiding more commoditised and routine tasks. Similarly, L2's HR function has introduced what it calls a modular approach to careers, which defines associates' careers as a series of development events and processes in which the firm promises to add value to the individual. In both cases, explicit development plans outlined the expected progress of associates, the ways in which they would enhance their skills and human capital and the sort of feedback they would receive. In one firm, associates were also given the opportunity to attend a business school program to enhance their general business knowledge.

Underpinning this career development model were new or more formalized HR policies of 'engagement' which all firms except L4 have introduced in the last five years. These typically included: frequent (up to 3 monthly) reviews for all associates; a major assessment process at the end of year four or five in the associate employment ladder in which career opportunities are outlined by the firm, prospects are explicitly discussed and associates receive feedback on their performance and prospects as well as a career development plan for the following two years; bonus 
systems based on performance (although some associates said this had become a norm, or 'an expected part of the pay packed, not a real performance bonus. The only surprise would be if someone did not get it.'; a structured career path from associate to a new grade of senior associate and an accompanying pay structure.

....We're saying, you know, for the brightest and the best, there is partnership available here and that's a very exciting and attractive prize. But for the majority of our people, you know, they're going to get the best possible experience and then they will go on and do lots of other different and exciting things. The way that I express it is that these are roles that are preserved for those people who we see as having a long term future with the firm.... (HR Manager, L1)

HR managers further supported the innovations in career development by using rhetoric of business needs. A broad career development model including alternative roles and career paths fits better with the firm's business model. However, this remained controversial and was not made wholly explicit in all firms. For example, one HR Manager said:

....We have been spending time thinking about - along with other firms - to answer your question about alternative career paths: is there a business model here that allows for people not necessarily to become partner but to have a career with us beyond the partnership promotion time for 7-8 years....we do have some men and women who have got some key specialisms who have stayed within the firm and got a career within the firm.. But it is not published as a particular career path in the firm because the partners wouldn't have it...but we are an exception in this respect. The other firms have got an alternative career path and we will in five years. [L2]

The HR Manager in Firm L3 summarized how the Of Counsel role was conceived and publicly presented:

Q: Why is (L3) introducing this new role?

A: When I came in to this job I thought, yeah, but investment banks don't say up-or-out, so why do we? In fact we had [permanent associates] for years. Each practice would make the 
exceptions and it was acceptable...We created a new permanent role and career path. It's for those who are partnership standard but for personal or business case reasons don't make partner...It's not a re-naming of associates...we have defined the role, pay and standards for those who will qualify. Counsel will work closely with partners and be included in partners' meetings...Partners have become more positive as they've 'lived it'.

The firm agreed the introduction of a new career path as an alternative to partnership believing there to be a business need for it and a desire amongst our associates.... The introduction of this title is for a select number of our Senior Associate, it's recognition of the key role they play in the Firm. While senior associates promoted to Of Counsel would not be excluded from becoming a partner at some point in the future it is recognised that a promotion to partner is likely to occur only rarely.

For all of the HR Managers, the tournament model of promotion contradicts with the changed economic and social environment (although in two cases, L4 and L7, its virtues were explicitly endorsed). In particular, it does not fit with the changing aspirations of young lawyers. As one HR director said: “Their aspirations are different from those of our partners and we have to bridge a generation gap”. It is also inconsistent with the notion of managing labour scarcity in a 'war for talent'. The upor-out model finds no explicit mention in the new career policies framed by HR Managers. As one HR Manager said:

[Up-or-out] is not a phrase I would recognise or find useful. It's not an accurate description of our policy. Who's doing the outing here? We don't do that in the sense of making a partner decision or forcing associates out if they fail.

The priority was to present the firm as a model employer which could attract and retain professional staff by providing career opportunities rather than emphasise competition for a limited number of partner slots. For example, one HR manager from a top law firm said: 
Retention is my biggest issue. I have been at my current firm for seven years and my focus throughout that time has been on recruitment. This year, for the first time, I am going to put recruiting to one side to focus on retention. We can't afford to have people we've brought in leaving. During the downturn it was easy to hire: people flooded out of City firms. Now those same City firms want people back. We can't compete on money or resources, so we need to be attractive in other ways to ensure we are holding on to what we have. (Head of HR, top50 regional firm, quoted in Legal Business assistant survey 2006:68)

HR Managers have therefore been the architects of innovation in alternative roles and new career routes. This has been challenging work as is reflected in this example quote from an HR manager:

Finally got this through at the fifth attempt in seven years (Of Counsel). The partners see it as a big risk. Most partners would believe this is an up-or-out firm if you ask them but in the absence of any data. So any innovation is a threat to that. Lawyers are binary, so they have no sense that you can have more than one policy running at the same time.

Firm L4 was the exception. The head of HR emphasised that "We are in a 'war for talent' insofar as we need to keep the machine going”, but despite this pressure and the absence of a formal up-or-out policy, the firm did not wish to retain associates beyond eight years qualified if they had not made partner. The firm recognised it would need to lose associates as they progressed and was, thus, mainly concerned with the timing of their departure, insofar as the median ideal service length was identified as three years after qualification. As the head of HR said:

The idea that people can go on ad infinitum is dangerous. The philosophy is that we want to replace the population. You don't want to sit on a fixed body of knowledge...

Unlike the other firms, L4 has chosen not to introduce employee engagement policies. Instead, it has retained its tradition of informal feedback from partners and a "fairly 
loose appraisal model”. Concurrently, formal career development focused on technical rather than social skills in enhancing associates’ human capital.

Partners. Partners were generally committed to the up-out-out model in principle and in most cases believed such a model existed in their firm. The up-or-out tournament was consistent with their professional and organizational values because it is instrumental in harnessing organizational reputation and professional expertise. Tournament systems ensure that only the "best-of-the-best" remain in the firm, while underperformers leave. One Of Counsel outlined how earlier in her career she had made the mistake of saying publicly to partners that she did not aspire to partnership and learned from that how badly this was viewed:

The deputy head of a group that I was thinking about moving to asked me to lunch with the head of the group. So I actually said at this lunch: 'What if I decided that I didn't want to be a Partner?' They said to me later: 'You should never say that to anybody else - that you might not want to be Partner.'(Of Counsel)

Partners perceive the up-or-out tournament as a means of maintaining an elite reputation, which in turn facilitates client acquisition and justifies higher hourly billings. From their perspective, the deferred compensation logic of promotion tournaments is an efficient incentive for aspiring candidates for partnership to collaborate fully and invest their personal capital in the interest of the firm.

Partners generally acknowledged that they do not have any formal rules enforcing an up or out or dismissing associates, but they recognized the existence of a de facto tournament. Partners also acknowledged that the up-or-out principle contradicted the new career roles, but that this contradiction was not very explicit in 
practice because the new roles were seen to some extent as window-dressing As one mid-ranking Partner from L5 put it:

Do we have up or out? It depends who is asking. If you asked the partners most of them would say yes. If you ask our HR director she'd probably disagree and point to the alternative careers we've got on offer and she's very persuasive. For our public face it's important we stress the careers opportunities.

While no partner openly expressed resistance to the idea of alternatives to partnership they rehearsed arguments highlighting the negative ramifications which are consistent with tournament theory. First, retaining senior associates was dysfunctional insofar as they took work and blocked the development of younger associates who would otherwise benefit from a learning experience. Second, they were expensive to employ and, unless they were guaranteed a constant stream of work requiring their level of qualification, were not good value for money. Third, employing permanent associates who knew they would never be considered for a partnership position presented a motivational risk. Fourth, it was suggested that the proliferation of permanent associates sent the wrong reputational signal to clients and the labour market as it indicated that the firm was not a "lean employer of the most ambitious associates, but had too many who were not quite out of the top quality drawer” (partner L2). Partners in general view the alternative roles as pragmatic adaptations the firms have had to introduce but are less comfortable with these being embedded as alternative career paths, specifically because of their ambiguous longterm implications for the firm's business model:

We have spent a lot of time thinking about this and still the partners are not comfortable with having a separate career path because it does really affect your business model. The model really is predicated on a partner working with associates to produce the kind of revenue that we require for our profits... and it is something that the partners find quite hard to engage with. They still cannot see how it could work. 
Managing Partners We interviewed either the managing partner or senior partner in each of the sample firms depending on who took prime responsibility for the executive activities in the area of promotion and was the officer to whom the HR director reported. These partners have managerial responsibilities for the firm but at the same time are partners and therefore operate with competing managerial and professional logics. For example, while they supported the business-based case for careers based on learning espoused by the HR directors, they expressed considerable support for the principle of up-or-out as a motivating device and a signal of quality to the labour market.

All but three (L7, L8, L10) took the view that the up-or-out model operated in practice in their firms. They explained that it was customary for associates to leave if passed over for promotion. Key to this was the rule in all firms that most associates had only a maximum of two attempts at the promotion process. As the managing partner of L9 said:

We never say never again but in practice its two shots at it, in exceptional circumstances three. I think we allowed a fourth for one associate but that was a complete exception. His group was just very insistent.

For the most part, failure at the second attempt was terminal. However, the managing partners tended to under-estimate the actual number of permanent associates in the firm.

We asked managing partners how the firm's internal labour market operated and how it was affected by the new roles. No firm had the sort of seeding model that Wilkins and Gulati (1998) postulate in their review of American firms whereby 
tournament 'winners' are selected early and given preferential treatment in terms of work and development. Managing partners and other partners said such seeding, tracking or strategic deployment was simply not viable, even if desirable, because it implied levels of resource planning and slack that were unrealistic. It also implied that partners took a longer term developmental view in selecting teams for transactions when the reality was overwhelmingly short term. Partners did implicitly rank associate quality but for task completion rather than promotion reasons and this 'hoarding' of associate time could have detrimental effects on career development as often as beneficial ones. Informally, all said a ‘sink or swim’ culture prevailed which weeded out poor quality associates early in their career and before promotion to partner was relevant.

When asked about the motivational implications of the new roles, partners and managing partners stated that for associates, motivation was simply not a problem and the motivation model was unaffected by these new roles. Asked to outline how motivation was achieved, partners and managing partners broadly summarised a model comprising several elements: first, selection for ambition as well as for technical skill; ambition need not necessarily be for partnership but for self development (general human capital acquisition), which the new career models sought to satisfy. Second, peer pressure among associate cohorts to perform and to get the opportunity to work on 'big deals'. Third, task pressure which was constant although its pattern varied from practice to practice and task feedback from senior associates and partners. Although all partners acknowledged that detailed feedback from partners was generally deficient, partners provided instant feedback via their reviews of associate drafting and other activities. Fourth, firms had taken more 
seriously formal appraisal systems for associates which, from the fourth year post qualification, discussed career implications. None thought the bonus system for associates was a major motivating device but was simply a necessity for labour retention.

Six of the managing partners concurred with the proposition that up-or-out was inconsistent in the longer run with the new roles that had been introduced. For managing partners this risk was indirectly a motivational one. Creating permanent non-partner roles did not undermine the motivational model of the core internal labour market of associates and partners but it could send the wrong message about the quality of the firm in the labour market if new roles like Of Counsel represented a new route to partnership. In L7, where there are permanent associates and new roles and the up-or-out did not operate, the managing partner said:

Actually, I think there is an issue down the road here. Its been too easy for associates to stay in the firm even if they did not make partner and I suspect we don't get the most motivated people as a result. We need Of Counsel and PSLs but we have to build a bit more of an edge, a stronger drive for success. Trouble is that practices always have compelling short term reasons for keeping associates.

Three managing partners took the view that the new roles were not problematic for up-or-out because they did not affect the core internal labour market structure. As the managing partner of L1 said:

You know, I used to think we didn't have up-or-out but I've thought more about it and come to the conclusion we do. In the end everyone becomes a partner or leaves this firm... Of Counsel won't change that because it's for a relatively small number of associates, relative to those who want to be partner. Our total population of Of Counsel will be much smaller than our partnership in the longer run. It'll be more difficult to be Of Counsel than to make partner. 
Associates. Our interview data from associates unravels an interesting complexity in their day to day engagement with the new firm policies encompassing alternatives to partnership. We interviewed associates at different stages of post-qualification (PQE) and across a range of practice areas. All associates consistently indicated that their firm (except L4) did not have an up-or-out policy and they were never explicitly asked to leave if they failed to make partner. Despite their belief that the firm did not enforce the up or out policy and a clear awareness of new alternative roles and careers reflected in firm policy, associates actively reinforced the notion that "leaving is the thing to do" if you did not make partner. As one associate said,

“No, but I think it's generally understood. I don't think the firm would have to tell people that".

Another stated this more forcibly:

If it does not happen, I would leave. That's my personal aspiration ... It's inconceivable that I would be asked to leave inconceivable. But I could not stay. I would be out of here very quickly.

In enacting their own career decisions the associates sustain the up or out. That associates are ensuring the continuity of the up-or-out practice is succinctly summarized in a comment by an HR Manager: “...up or out occurred in practice where associates made the decision....”.

Paradoxically, associates who had been appointed to alternative roles reinforced the status quo. When asked about her views on the extent to which an upor-out system existed, an Of Counsel replied: “(laughs)....well I guess not. I am an example of up and going nowhere....”. She continued to explain how the new role was perceived by her supervisors and herself: 
I knew that my chances of being put forward for partnership were small as there was no business case in my group and I never had a mentor. But when the Of Counsel thing came out the partners said to me that they were not going to put me forward because that would be sending 'the wrong message' because my appraisal has been what I need to do to be a partner, all that kind of stuff. But it got me thinking ...I thought there is only so much knocking on the door almost closed to you [partnership prospects]. So this is what I would like to do. So I went for it. But then when it came out in September, the announcement and people were congratulating me, I did feel it was a bit of a cop-out and I felt, why are you congratulating me because I have kind of down graded.

Associates appointed to the role of Professional Support Lawyers also

expressed scepticism about how the role was perceived in the firm and also expressed

frustration around the lack of a career structure for PSLs. One PSL at L2 commented:

... I was offered what they called at the time a secondment to PSL to begin with for six months. But I think the firm's expectation or wish was that I would go back to fee-earning at the end of it....but actually having had a glimpse into professional support, it worked for me. The slight frustration is that there is an absenc of a career structure (for PSLs)....My aim is to hang around for a period of not longer than twelve months and see if the firm does anything about PSL career structures and if they don’t it is quite possible that I will leave...

Another PSL at firm L5 opted for a PSL role but came back to fee earning after a year because she decided “it wasn’t for her”. She noted that the PSL role had been very good in raising her profile but even so she suspected that the perception in the firm was that "I took the year out. So I think, I suspect it's not going to be as helpful as I would have liked to have thought that it might have been...”

\section{Discussion}

The introduction (or extension) of various alternatives to partner roles including Of Counsel, Permanent Associates, Professional Support Lawyers all provide permanent employment to associates who are not promoted to partner. This 
raises the question of how firms seek to counterbalance the motivational deficiencies that are theoretically implied by challenging the orthodox model of the up-or-out promotion. To answer this we examined the motivation for introducing alternative roles, the perception of actors as to how these roles fitted with the traditional internal labour market model of the firm and how the issue of employee motivation was managed.

First, we found that a formal up-or-out policy did not usually exist but that the practice of not retaining associates if they were passed over for promotion to partner was nonetheless a customary norm in the majority of these firms. Partners saw the upor-out as an important indicator of reputation and means of maintaining labour quality as well as a motivating device. However, not having a formal policy offered some flexibility to the way the up-or-out rule was actually applied. Firms tolerated exceptions to the rule with differing degrees of latitude. Even the firm (L4) that most explicitly operated with this rule was flexible enough to employ permanent associates.

Latitude occurs because all firms acknowledge that practice groups, the expertise-based organising unit for teams of professionals, work with different leverage models. Fundamentally, the up-or-out model worked best in the core corporate finance practices where, as one partner put it, 'No one would want to stick around (if failing to make partner) and become a forty-five year old bag carrier but in tax or employment it's a different matter.' To the extent that these firms are better conceptualised as constellations of practices rather than unitary organisations, variations in internal labour market structures at the practice group level are highly likely (Anand, Gardner and Morris, 2007). This is reinforced by the relatively 
decentralised nature of the firm's management and the autonomy that local, practice group partners retain to deliver client services (Greenwood et al 1990). As a result, even strongly embedded promotion systems like the up-or-out vary in application.

Second, we find that alternative models of career are justified on rational grounds as being consistent with new business conditions. In other words, the assumption has been that reform of promotion systems is a catching up exercise to some extent to re-align the internal labour market with new conditions of labour supply and more complex demand patterns prompted by the diversification and internationalisation of these firms.

The role of human resource professionals was critical here. As part of the process of introducing greater managerialism, such professional support staff have assumed increasingly influential positions. The establishment of new roles and the rhetoric of careers are evidence of the working of that influence and of a different sort of logic in managing the internal labour market. Human resource managers tend to emphasise that there is no formal up-or-out policy. They also emphasise the contradictions of any such policy with organisational goals of growth and labour retention and they see little motivational value in an up-or-out policy compared to policies that they have introduced. New career models emphasise a contract of 'learning', that is the acquisition by associates of general human capital that is broader than sheer technical skill, in return for high employee commitment.

Third, we found that it is associates themselves who enforce the up-or-out practice. While no formal policy exists, associates learn from each other and from the 
rhetoric of partners that the offer of partnership is the longer term prize and that failure is incompatible with a permanent position. Indeed, firms signal the value of promotion to partner by establishing two-tier tournaments. The growing influence of ranking exercises that emphasise the metric of profit-per-partner also serves to escalate the importance of the competition for promotion to an equity position. The consequence of this is that up-or-out retains motivational power even though it is not a formal policy and alternative careers exist. New roles provide supplementary opportunities for a relatively small number of associates but are not a wholesale replacement for the up-or-out system.

\section{Conclusion}

The question motivating this research was how professional partnership firms were adapting to pressures to reform their promotion systems without losing the benefits of the up-or-out model. We focused on a set of elite law firms in the UK and we investigated the changes the firms had introduced to their promotion policies. By interviewing a range of actors inside the firm including those associates who are the object of these policies, we show how these new policies were enacted. This is important because we show the limits of new policies focused on the creation of a set of new roles that challenge the up-or-out model by establishing permanent roles for those that do not necessarily make partner and in some cases present a different route to partnership. Few associates are attracted to these roles, however, as they violate the underlying assumption that there are only two core roles in the internal labour market. We also find that a majority of firms have introduced new career models that are built around the notion of learning in exchange for commitment and do not assume that all associates will seek to participate in the up-or-out tournament. Firms therefore operate 
with two motivational models, which are broadly seen as complementary rather than contradictory. Nevertheless, the salience of the up-or-out persists, principally because the majority of associates who seek promotion to partnership enact it. To the extent and in the ways that it sustains the internal labour market of these professional firms, it is more than the metaphor and yet less than the sophisticated selection process that Wilkins and Gulati (1998) claim to have observed in American firms.

\section{References}

Anand, N., Gardner, H., and Morris, T. (2007), 'Knowledge-Based Innovation: Emergence and Embedding of New Practice Areas in Management Consulting Firms,' Academy of Management Journal, 50, 6, 1554-1557.

Galanter, M., and Palay, T. (1991), Tournament of Lawyers: The Transformation of the Big Law Firm, Chicago: University of Chicago Press.

Galanter, M. and Henderson, W.D. (2008), 'The Elastic Tournament: The Second Transformation of the Big Law Firm,' Stanford Law Review, 60, 102-164.

Gilson, R.J., and Mnookin, R.H. (1985), 'Sharing Among The Human Capitalists: An Economic Inquiry into the Corporate Law Firm and How Partners Split Profits,' Stanford Law Review, 37, 2, 313-392.

Gilson, R.J., and Mnookin, R.H. (1989) 'Coming of Age in a Corporate Law Firm: The Economics of Associate Career Patterns,’ Stanford Law Review, 41, 3, 567-595.

Greenwood, R., Hinings, C.R. and Brown, J.L. (1990), 'P² Form Strategic Management: Corporate Practices in Professional Partnerships,' Academy of Management Journal, 33, 725-55.

Greenwood, R., Li, X., Prakash, R., and Deephouse, D. (2005) 'Reputation, Diversification, and Organizational Explanations of Performance in Professional Service Firms,' Organization Science, 16, 6, 661-673.

Greenwood, R., Suddaby, R., and M. McDougald (2007), 'Introduction', in Research in the Sociology of Organizations, 24, 1-17.

Hitt, M., Bierman, L., Shimizu, K., and Kochlar, R. (2001), 'Direct and Moderating Effects of Human Capital on Strategy and Performance in Professional Service Firms: A Resource-Based Perspective,' Academy of Management Journal, 44, 13-28.

Kordana, K. (1995), 'Law Firms and Associate Careers: Tournament Theory Versus 
The Production-Imperative Model,' Yale Law Journal, 104, 1907-1934.

Landers, R., Rebitzer J., and Taylor, L. (1996), 'Rat Race Redux: Adverse Selection In The Determination Of Work Hours In Law Firms,' The American Economic Review, 86, 3, 329-348.

Lazear, E.P., and Rosen, S. (1981), 'Rank-Order Tournaments As Optimum Labor Contracts,’ The Journal of Political Economy, 89, 5, 841-864.

Malos, S., and Campion, S. (1995), 'An Option-Based Model of Career Mobility in Professional Service Firms,’ Academy of Management Review, 20, 611-645.

Morris, T., and Pinnington, A. (1998), 'Promotion to Partner in Professional Service Firms,' Human Relations, 51, 3-24.

Morris, T., and Pinnington, A. (2002), 'Beyond the 'War for Talent' Hype: Occupational and Organizational Change in the Business Professions' in Management and Organization Paradoxes, ed. S. Clegg, Amsterdam: John Benjamins Publishing Company.

Sharma, A. (1997), 'Professional As Agent: Knowledge Asymmetry In Agency Exchange,' Academy of Management Review, 22, 758-798.

Sherer, P. (1995), 'Leveraging Human Assets in Law Firms: Human Capital Structures and Organizational Capabilities,' Industrial and Labor Relations Review, 48, 671-691.

Sherer, P., and Lee. K. (2002), 'Institutional Change in Large Law Firms: A Resource Dependency and Institutional Perspective,' Academy of Management Journal, 45, 102-119.

Starbuck, W. (1992), 'Learning by knowledge-intensive firms', Journal of Management Studies, 29, 6, 713-740.

Wilkins, D. B. and Gulati, M. (1998), 'Reconceiving the Tournament of Lawyers: Tracking, Seeding, and Information Control in the International Labor Markets of Elite Law Firms,' Virginia Law Review, 84, 1581-1681. 


\section{Appendix}

Table 1 Alternative roles and new career policies

\begin{tabular}{|c|c|c|c|c|c|c|c|c|c|c|}
\hline & L1 & L2 & L3 & L4 & L5 & L6 & L7 & L8 & L9 & L10 \\
\hline Of Counsel & yes & $\begin{array}{l}\text { no (exist } \\
\text { informally) }\end{array}$ & yes & no & yes & yes & yes & no & yes & no \\
\hline $\begin{array}{l}\text { Salaried } \\
\begin{array}{l}\text { Partners } \\
\text { (and ratio of } \\
\text { salaried to } \\
\text { equity partners) }\end{array}\end{array}$ & $\begin{array}{l}\text { yes } \\
20\end{array}$ & $\begin{array}{l}\text { yes } \\
55\end{array}$ & $\begin{array}{l}\text { yes } \\
29\end{array}$ & 5 & 68 & $\begin{array}{l}\text { yes } \\
10\end{array}$ & 20 & $\begin{array}{l}\text { yes } \\
130\end{array}$ & $\begin{array}{l}\text { no } \\
4\end{array}$ & $\begin{array}{l}\text { yes } \\
100\end{array}$ \\
\hline PSL & yes & yes & yes & yes & yes & yes & yes & yes & yes & yes \\
\hline $\begin{array}{l}\text { permanent } \\
\text { associates } \\
\text { formally } \\
\text { acknowledged }\end{array}$ & no & no & no & no & no & no & yes & yes & yes & yes \\
\hline $\begin{array}{l}\text { OC: } \\
\text { individual } \\
\text { bonus }\end{array}$ & yes & no & $\begin{array}{l}\text { Yes } \\
\text { (but } \\
\text { small) }\end{array}$ & NA & yes & yes & yes & NA & yes & NA \\
\hline $\begin{array}{ll}\text { OC: } & \text { profit } \\
\text { share } & \end{array}$ & no & yes & yes & NA & no & no & no & NA & yes & NA \\
\hline $\begin{array}{l}\text { OC: } \\
\text { consultation } \\
\text { rights }\end{array}$ & yes & no & yes & NA & yes & no & no & NA & no & NA \\
\hline $\begin{array}{l}\text { OC route to } \\
\text { partner }\end{array}$ & no & $\begin{array}{l}\text { yes but } \\
\text { informal }\end{array}$ & no & no & yes & $\begin{array}{l}\text { yes } \\
\text { (but } \\
\text { pathway } \\
\text { not } \\
\text { defined) }\end{array}$ & $\begin{array}{l}\text { yes } \\
\text { (but } \\
\text { pathway } \\
\text { not } \\
\text { defined) }\end{array}$ & NA & no & NA \\
\hline $\begin{array}{l}\text { New careers } \\
\text { policy }\end{array}$ & yes & $\begin{array}{l}\text { no (but } \\
\text { pressing } \\
\text { for one) }\end{array}$ & yes & no & yes & yes & yes & no & yes & no \\
\hline
\end{tabular}

